\title{
Karaktristik proses destilasi asap cair grade 3
}

\author{
Kemas Ridhuan $^{1 *}$, Tri Cahyo Wahyudi ${ }^{2}$, Danang Sulistiyo ${ }^{3}$, Bahtera Anggara ${ }^{4}$ \\ ${ }^{1,2,3,4}$ Program Studi Teknik Mesin, Fakultas Teknik, Universitas Muhammadiyah Metro \\ JI. Ki Hajar Dewantara 15 A Kota Metro, Lampung. \\ ${ }^{*}$ Corresponding author: kmsridhuan@yahoo.co.id
}

\begin{abstract}
Distillation of liquid smoke is a process of heating liquid smoke based on the difference in its boiling point and then cooled to get liquid smoke with better quality. This heating aims to separate unwanted components in liquid smoke such as tar and benzopyrene. The process is strongly influenced by several things such as temperature and distillator. From these two measurements, several characteristics such as heating rate, distillation flow rate of liquid smoke, production capacity, heating temperature, steam temperature and distillation time, as well as the characteristics of the resulting liquid smoke can be known. The purpose of this study is to determine the characteristics of the $3^{\text {rd }}$ grade liquid smoke distillation process with electric heating and water cooling condenser which includes the production capacity of liquid smoke and to determine the quality and quantity of liquid smoke, heating rate, electricity consumption, flow rate and to determine the efficiency of $2^{\text {nd }}$ grade liquid smoke production. This research was conducted at the Laboratorium Teknik Mesin Universitas Muhammadiyah Metro, this study used a distillation apparatus made of Aluminium plate $1 \mathrm{~mm}$ thick, $180 \mathrm{~mm}$ in diameter, $250 \mathrm{~mm}$ high. Condenser with 0.5 inch diameter copper pipe 3,5 $\mathrm{m}$ long, 3 inch diameter PVC pipe, $3 \mathrm{~m}$ long. The raw material for $3^{\text {rd }}$ grade liquid smoke is 3 liters. The results obtained that the distillation apparatus has a capacity of 3 liters, the distillation temperature affects the rate of heating that occurs, namely the distillation temperature of $110^{\circ} \mathrm{C}$, the heating rate is $707,42 \mathrm{~J} / \mathrm{second}$, the electricity consumption is $4,48 \mathrm{kWh}$, the time is 45 minutes, and for a temperature of $120^{\circ} \mathrm{C}$ the heating rate is 754,60 J/second, electricity consumption is 4,467 kWh in 65 minutes. The highest yield of liquid smoke is at a temperature of $110^{\circ} \mathrm{C}$, which is $2840 \mathrm{ml}$ with a flow rate of 8,35 $\mathrm{ml} / \mathrm{minute}$ and an efficiency of 94,6\%, $\mathrm{pH}$ level of 2,15. And for a temperature of $120^{\circ} \mathrm{C}$ it produces $2560 \mathrm{ml}$ of liquid smoke, with a flow rate of 8,67 ml/minute and an efficiency of $85,3 \%$, with a $\mathrm{pH}$ level of 2,10.
\end{abstract}

Keywords: Distillation, heating, liquid smoke, efficiency, condenser.

\begin{abstract}
Abstrak
Destilasi asap cair merupakan suatu proses pemanasan pada asap cair berdasarkan perbedaan titik didihnya kemudian didinginkan untuk mendapatkan asap cair dengan kualitas yang lebih baik. Pemanasan ini bertujuan untuk memisahkan komponen yang tidak diharapkan pada asap cair seperti tar dan benzopiren. Proses tersebut sangat dipengaruhi oleh beberapa hal seperti suhu dan destilator. Dari dua ukuran tersebut dapat diketahui beberapa karaktristik seperti laju pemanaasan, laju aliran destilasi asap cair, kapasitas produksi, suhu pemanasan, suhu uap dan waktu destilasi, serta karakteristik asap cair yang dihasilkan. Tujuan penelitian ini yaitu mengetahui karakteristik proses destilasi asap cair grade 3 dengan pemanas listrik dan kondensor pendingin air yang meliputi kapasitas produksi asap cair dan mengetahui kualitas dan kuantitas hasil asap cair, laju pemanasan, pemakaian daya listrik, debit aliran, serta mengetahui efisiensi hasil produksi asap cair grade 2. Penelitian ini dilakukan di Laboratorium Teknik Mesin Universitas Muhammadiyah Metro, penelitian ini menggunakan alat destilasi berbahan pelat Aluminium tebal $1 \mathrm{~mm}$, diameter $180 \mathrm{~mm}$, tinggi
\end{abstract}


$250 \mathrm{~mm}$. Kondensor dengan pipa tembaga berdiameter 0,5 inchi dengan panjang 3,5 m, pipa pvc berdiameter 3 inch, panjang $3 \mathrm{~m}$. Bahan baku asap cair grade 3 sebanyak 3 liter. Hasil penelitian yang didapatkan Alat destilasi memiliki kapasitas 3 liter. Suhu destilasi berpengaruh terhadap laju pemanasan yang terjadi yaitu suhu destilasi $110^{\circ} \mathrm{C}$ laju pemanasan $707,42 \mathrm{~J} /$ detik, pemakaian listrik 4,48 $\mathrm{kWh}$, waktu 45 menit, dan untuk suhu $120{ }^{\circ} \mathrm{C}$ laju pemanasan 754,60 J/detik, pemakaian listrik 4,467 kWh waktu 65 menit. Hasil asap cair terbanyak yaitu pada suhu $110^{\circ} \mathrm{C}$ yaitu $2840 \mathrm{ml}$ dengan debit aliran $8,35 \mathrm{ml} / \mathrm{menit}$ dan efisiensi 94,6\%, kadar pH 2,15. Dan untuk suhu $120{ }^{\circ} \mathrm{C}$ menghasilkan asap cair $2.560 \mathrm{ml}$, dengan debit aliran 8,67 ml/menit dan efisiensi 85,3\%, kadar $\mathrm{pH}$ 2,10.

Kata kunci: Destilasi, pemanasan, asap cair, efisiensi, kondensor.

\section{Pendahuluan}

Asap cair atau suka disebut juga cuka kayu merupakan cairan organik alami yang dihasilkan dari proses kondensasi asap pada proses pembakaran pirolisis. Produksi asap cair merupakan hasil pembakaran tidak sempurnan yang mengakibatkan reaksi dekomposisi karena pengaruh panas, kondensasi dan polimerisasi [1]. Pembakaran tersebut dengan jumlah oksigen terbatas yang melibatkan reaksi dekomposisi bahan polimer menjadi komponen organik dengan bobot yang lebih rendah. Asap cair/cuka kayu berwarna kuning kecoklatan sampai kehitaman dan berbau menyengat. Menurut Hambali (2007) asap cair merupakan salah satu bahan bakar cair berwarna kehitaman yang berasal dari biomassa seperti kayu, kulit kayu, dan limbah industri [2].

Asap cair adalah bahan yang multiguna, yaitu bisa dipakai sebagai bahan apa saja yaitu seperti pengawet makanan, bahan antiseptic, pupuk cair tanaman, bahan anti rayap pada kayu dan penggumpal lateks. Asap cair mengandung lebih dari 400 komponen dan memiliki fungsi sebagai penghambat perkembangan bakteri dan cukup aman sebagai pengawet alami [3].

Ukuran kualitas asap cair dapat dikelompokan menjadi 3 yaitu Grade 1 merupakan kualitas terbaik dengan warna putih bening. Grade 2 kualitas sedang dengan warna kekuning-kuningan dan Grade 3 dengan warna kehitam-hitaman. Asap cair Grade 3 tersebut didapat dari proses pirolisat asap cair dengan bau yang sangat menyengat dan masih banyak mengandung tar dan bahan berbahaya lainnya dan belum bisa dipakai sebagai bahan pengawet makanan. Maka asap cair Grade 3 tersebut harus difraksinasi dengan destilasi. Untuk mendapatkan asap cair Grade 2 atau 1 maka perlu dilakukan destilasi dari asap cair Grade 3 tersebut di dalam sebuah destilator.

Destilasi asap cair merupakan salah satu metoda pemisahan asap cair berdasarkan perbedaan titik didihnya. Menurut Yaman (2004) destilasi adalah suatu cara pemisahan larutan dengan menggunakan panas sebagai pemisah atau separating agent. Destilasi ini bertujuan untuk mendapatkan sifat fungsional dari asap cair, serta menghilangkan senyawa yang tidak diinginkan seperti tar dan benzopiren. Destilasi ulang atau redestilasi merupakan cara untuk mendapatkan hasil kualitas asap cair yang lebih baik dari asap cair sebelumnya [4]. Proses destilasi asap cair juga dapat menghilangkan senyawa yang tidak diinginkan yaitu senyawa tar dan hidrokarbon polisikis aromatik [5].

Untuk proses destilasi ini diperlukan suatu rangkaian peralatan yaitu seperti reaktor atau tabung penampung asap cair yang juga sebagai tempat pemanasan beserta alat pemanasnya yang berfungsi untuk mengubah asap cair menjadi uap. Kemudian kondensor merupakan tempat pendinginan uap asap cair yang dipanaskan tadi sehingga menjadi cairan asap cair kualitas terbaik. Kondensor terdiri dari pipa tembaga sebagai saluran asap cair yang telah didinginkan. Lalu tabung atau silinder penampung air pendingin asap atau uap. 
Hasil dari destilasi ini sangat tergantung pada beberapa hal diantaranya suhu pemanasan asap cair. Destilasi asap cair dapat dilakukan pada suhu $100^{\circ} \mathrm{C}$ hingga $150^{\circ} \mathrm{C}$ menurut [5]. Semakin besar suhu pemanasan maka semakin banyak asap cair yang diuapkan sehingga akan semakin banyak pula hasil asap cair yang didapatkan dengan laju aliran asap cair yang tinggi. Kemudian itu pula waktu destilasi yang terjadi akan lebih cepat, karena produksi uap akan meningkat. Menurut Ridhuan (2020) bahwa semakin tinggi suhu dan lama waktu maka semakin banyak asap cair yang dihasilkan, dan efisiensi asap cair tertinggi pada jenis kayu rengas yaitu $0,65 \%$ dan efisiensi terendah pada kayu jati putih yaitu $0,27 \%$. Namun peningkatan produksi uap asap cair yang juga harus diimbangi oleh kinerja kondensasi pada kondensornya, sehingga seluruh uap asap akan terkondensasi menjadi cairan semua. Jika ada sebagian asap cair yang tidak terkondensasi dengan baik maka akan ada kehilangan sebagian uap asap cair ke udara luar. Sehingga hal ini akan menurunkan efisiensi produksi destilasi dan destilasi ulang (redestilasi) asap cair [6].

Kualitas dan kuantitas asap cair sangat tergantung juga pada proses destilasi di kondensor, seperti kejernihannya. Suhu air pendingin kondensor akan menentukan banyaknya asap cair yang didapat. Maka air pendinginnya dibuat mengalir dengan debit tertentu. Selain itu, beberapa senyawa toksik, terutama Polycyclic Aroniafic Hydrocarbons (PAH) yang dihasilkan dari proses pembakaran lebih mudah dikontrol. Selain itu pula bahwa suhu pemanasan asap cair tersebut juga akan mempengaruhi kualitas hasil asap cair yang didapat. Ada beberapa komponen atau kandungan dari asap cair yang terurai. Menurut Darmadji, (2002) bahwa optimasi redestilasi adalah pada kondisi suhu redestilasi $122,5^{\circ} \mathrm{C}$, waktu redestilasi antara 69 menit dan suhu kondensasi antara $24^{\circ} \mathrm{C}$. Pada kondisi optimum tersebut kadar tar tidak tertera, sedangkan kadar fenol, karbonil dan asam berturut-turut : 2,24\%, 5,60\% dan $15,7 \%$ serta rendemenya 42,2 \% [5]. Kemudian Yulistiani (2008) mengatakan bahwa ridestilasi asap cair dilakukan untuk menghilangkan senyawa-senyawa yang tidak diinginkan dan berbahaya seperti poliaromatik hidrokarbon (PAH) dan tar, dengan cara pengaturan suhu didih sehingga diharapkan didapat asap cair yang jernih, bebas tar dan benzopiren [7].

\section{Metode Penelitian}

Metode penelitian yang digunakan yaitu perancangan, pembuatan dan pengujian alat destilasi dan kondensornya skala lab. Dengan pemanas listrik berdaya 800 Watt. Silinder atau reaktor destilator berdiameter $20 \mathrm{~cm}$, tinggi $25 \mathrm{~cm}$ berbahan aluminium dengan tebal $1 \mathrm{~mm}$. Menggunakan kondensor pipa lurus berpendingin air yang mengalir debit 5 liter/menit, dengan diameter pipa luar PVC 3 inch dan diameter pipa dalam tembaga 12 $\mathrm{mm}$, panjang 3 meter. Memvariasikan suhu destilasi pada $110^{\circ} \mathrm{C}, 115^{\circ} \mathrm{C}$ dan $120^{\circ} \mathrm{C}$. Menggunakan asap cair Grade 3 dari proses pirolisis sebanyak 3 liter.

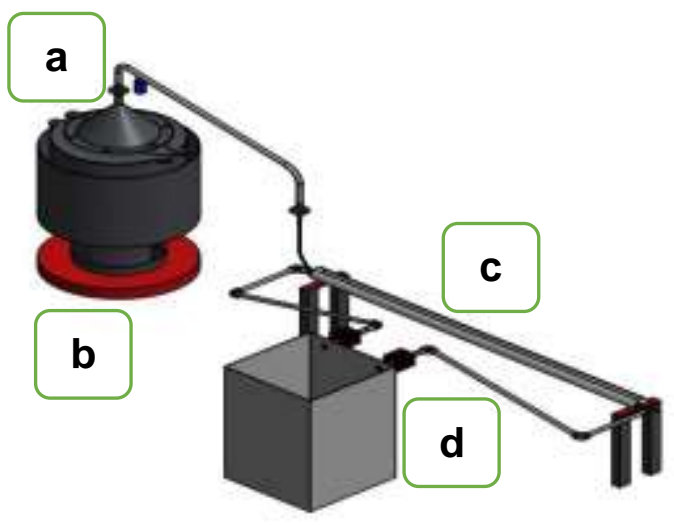

$$
\begin{aligned}
& \text { Gambar 1. Rangkaian Alat Destilasi dan } \\
& \text { Pendinginnya. }
\end{aligned}
$$

Keterangan Gambar :

a. Alat Destilasi

b. Pemanas Listrik

c. Kondensor

d. Penampung Air Pendingin

Alat destilasi merupakan alat yang berfungsi untuk pemisahan suatu bahan 
(cairan) berdasarkan perbedaan kecepatan ataupun kemudahan menguap (volatilitas). Asap cair Grade 3 yang merupakan hasil proses pirolisis dimasukan ke dalam reaktor destilasi. Alat destilasi diletakkan di atas pemanas listrik. Pemanas listrik dihidupkan. Data pengujian dicatat seperti suhu di berbagai titik, waktu, dan hasil asap cair yang telah terdestilasi.

Setelah beberapa menit, maka suhu destilasi asap cair akan tercapai yaitu $110^{\circ} \mathrm{C}, 115^{\circ} \mathrm{C}$, dan $120^{\circ} \mathrm{C}$. Asap cair yang menguap (berbentuk uap) akan keluar dari reaktor dan memasuki kondensor. Di kondensor uap asap cair tersebut didinginkan sehingga menjadi cairan lagi (asap cair Grade 2) yang menetes di pipa tembaga keluar kondensor. Hasil asap cair ini warnanya lebih bening (putih kekuningan).

Dalam pendinginan di kondensor tersebut, air pendingin harus mengalir, karena pemanasan tersebut suhunya sangat tinggi. Alat destilasi tersebut harus memiliki beberapa keunggulan seperti bahannya memiliki penghantar panas yang baik, kokoh, dan kuat. Pemanasnya harus memiliki daya yang cukup tinggi minimal 800 Watt. Kapasitas reaktor dan diameter pipa tembaga kondensor harus memiliki ukuran yang sebanding agar didapat hasil asap cair dengan efisiensi yang tinggi.

\section{Hasil dan Pembahasan}

Setelah dilakukan pengujian dengan memvariasikan suhu destilasi asap cair yaitu $110^{\circ} \mathrm{C}, 115^{\circ} \mathrm{C}$ dan $120^{\circ} \mathrm{C}$, maka didapat beberapa hasil sebagai berikut :

Tabel 1. Karakteristik asap cair

\begin{tabular}{ccccc}
\hline No & Asap cair & $\mathrm{pH}$ & $\begin{array}{c}\text { Banyak } \\
\text { asap cair } \\
(\mathrm{ml})\end{array}$ & $\begin{array}{c}\text { Waktu } \\
\text { (menit) }\end{array}$ \\
\hline 1 & $\begin{array}{c}\text { Bahan baku } \\
\text { Grade } 3\end{array}$ & 2,46 & 3000 & \\
\hline 2 & $\begin{array}{c}\text { Destilasi } \\
\left(110^{\circ} \mathrm{C}\right)\end{array}$ & 2,15 & 2840 & 380 \\
\hline 3 & $\begin{array}{c}\text { Destilasi } \\
\left(115^{\circ} \mathrm{C}\right)\end{array}$ & 2,16 & 2740 & 365 \\
\hline 4 & $\begin{array}{c}\text { Destilasi } \\
\left(120^{\circ} \mathrm{C}\right)\end{array}$ & 2,10 & 2560 & 355 \\
\hline
\end{tabular}

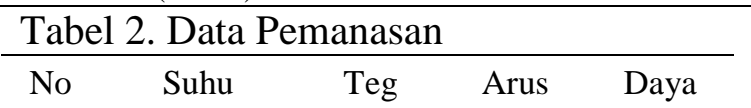

\begin{tabular}{ccccc}
\hline & $\begin{array}{c}\text { Destilasi } \\
\left({ }^{\circ} \mathrm{C}\right)\end{array}$ & (Volt) & (Amp) & (Watt) \\
\hline 1 & 115 & 217 & 3,26 & 707,42 \\
\hline 2 & 120 & 219 & 3,42 & 748,98 \\
\hline 3 & 125 & 220 & 3,43 & 754,60 \\
\hline
\end{tabular}

Beberapa data yang didapat dari hasil pengujian eksperimental dan data dari hasil pengolahan (perhitungan) ini tidak dapat ditampilkan lebih banyak mengingat ruangnya terbatas dan hanya ditampilkan data pokonya saja.

Berikut beberapa gambar grafik yang telah dibuat darai beberapa data yang didapat dan data pengolahan.

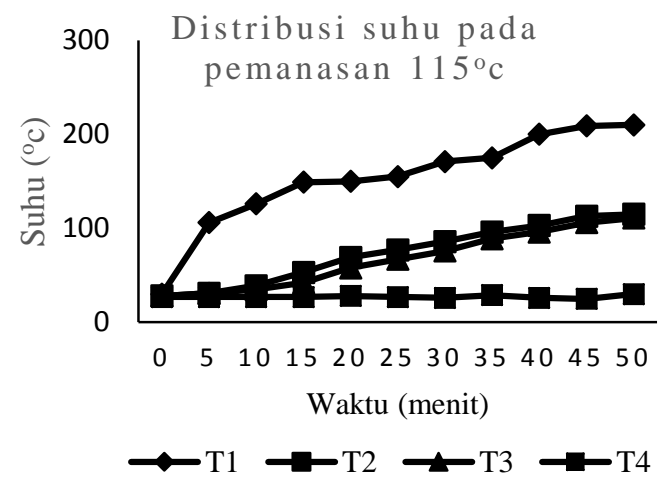

Gambar 2. Pengujian tiap titik pada suhu destilasi $115^{\circ} \mathrm{C}$.

Pada gambar 2 ditampilkan grafik perbandingan suhu terhadap waktu pada suhu destilasi $115^{\circ} \mathrm{C}$, sebagai contoh untuk menunjukan kondisi suhu di tiap titik pengujian. Terlihat bahwa suhu pada kompor pemanas $\left(\mathrm{T}_{1}\right)$ selalu mengalami kenaikan pada saat awal dihidupkan karena digunakan untuk memanaskan asap cair hingga mencapai suhu $115^{\circ} \mathrm{C}$. Pada grafik ini terlihat perbadaan antara $\left(\mathrm{T}_{1}\right)$ dan $\left(\mathrm{T}_{2}\right)$ dimana dibutuhkan suhu $210^{\circ} \mathrm{C}$ pada kompor untuk memanaskan asap cair didalam reaktor hingga mencapai suhu $115^{\circ} \mathrm{C}$. Kemudian untuk suhu $\left(\mathrm{T}_{3}\right)$ pada saat suhu sudah konstan yaitu $111^{\circ} \mathrm{C}$. Suhu $\left(\mathrm{T}_{4}\right)$ sendiri dari awal proses destilasi sampai akhir yaitu antara $27^{\circ} \mathrm{C}-35^{\circ} \mathrm{C}$. Pada grafik ini untuk suhu untuk $\left(\mathrm{T}_{4}\right)$ dan $\left(\mathrm{T}_{3}\right)$ selalu mengalami kenaikan dari awal hingga waktu 50 menit. 
Pada gambar 3, pengaruh variasi suhu destilasi terhadap laju perubahan suhu dapat diketahui bahwa laju perubahan suhu yang paling cepat adalah pada suhu $110{ }^{\circ} \mathrm{C}$ yaitu dimulai dari suhu awal $28{ }^{\circ} \mathrm{C}$ untuk mencapai suhu $110{ }^{\circ} \mathrm{C}$ hanya memerlukan waktu 45 menit (gambar 3) dan laju perubahan suhunya $1,82^{\circ} \mathrm{C} /$ menit dan laju pemanasannya $707,42 \mathrm{~J} /$ detik Selanjutnya pada suhu $115{ }^{\circ} \mathrm{C}$ sama-sama dimulai dari suhu $28{ }^{\circ} \mathrm{C}$ untuk mencapai suhu $115{ }^{\circ} \mathrm{C}$ memerlukan waktu 50 menit dan laju perubahan suhunya $1,74{ }^{\circ} \mathrm{C} / \mathrm{menit}$ dan laju pemanasannya $748,98 \mathrm{~J} /$ detik Dan pada suhu $120{ }^{\circ} \mathrm{C}$ dimulai dari suhu $28{ }^{\circ} \mathrm{C}$ sampai ke suhu $120{ }^{\circ} \mathrm{C}$ memerlukan waktu yang lebih lama yaitu 65 menit dengan laju perubahan suhu $1,41{ }^{\circ} \mathrm{C} /$ menit dan laju pemanasannya $754,60 \mathrm{~J} /$ detik.

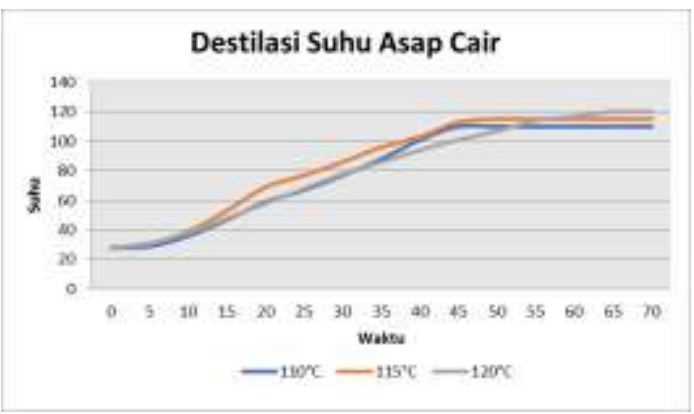

Gambar 3. Perbandingan suhu destilasi

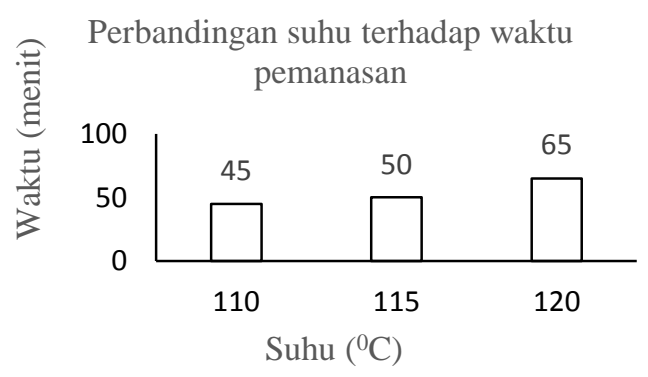

Gambar 4. Grafik perbandingan suhu terhadap waktu pemanasan

Pada gambar 4, dapat dilihat perbedaan laju perubahanan suhu bahwa semakin kecil suhu $\left(110^{\circ} \mathrm{C}\right)$ yang akan dicapai maka semakin besar laju perubahan suhu yang terjadi $\left(1,82^{\circ} \mathrm{C} /\right.$ menit $)$. Dan sebaliknya semakin besar suhu $\left(120^{\circ} \mathrm{C}\right)$ maka semakin kecil laju perubahan suhunya $\left(1,41^{\circ} \mathrm{C}\right)$. Hal ini terjadi karena apabila suhu yang akan dicapai kecil maka akan membutuhkan waktu yang cepat dan laju pemberian panas yang sama besar, karena waktu sangat berpengaruh sebagai pembagi terhadap laju pemanasan yang terjadi.

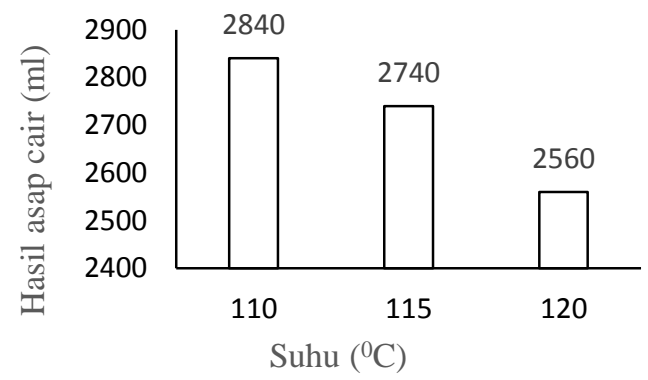

Gambar 5. Grafik perbandingan suhu terhadap hasil asap cair

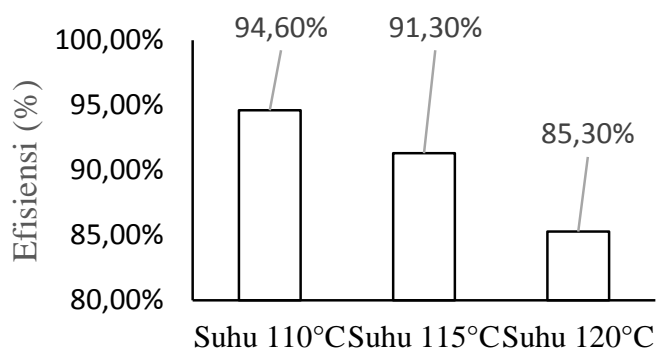

Gambar 6. Grafik perbandingan efisiensi hasil asap cair

Hasil asap cair sangat berhubungan dengan suhu destilasinya, seperti pada gambar 5. terlihat bahwa suhu destilasi kecil $\left(110^{\circ} \mathrm{C}\right)$ menghasilkan asap cair yang banyak yaitu $2840 \mathrm{ml}$ atau dengan efisiensi 94,6\% (gambar 5.10), Kemudian pada suhu $115{ }^{\circ} \mathrm{C}$ didapatkan asap cair sebanyak 2740 $\mathrm{ml}$ atau efisiensi $91,3 \%$. Sebaliknya suhu destilasi tinggi $\left(120^{\circ} \mathrm{C}\right)$ akan menghasilkan asap cair yang sedikit yaitu $2560 \mathrm{ml}$ atau efisiensi 85,3\% (gambar 5.10). hal ini dikarenakan bahwa semakin rendah suhu destilasi maka akan semakin sedikit uap asap cair yang dihasilkan dan laju penguapan juga kecil sehingga akan semakin sedikit uap asap cair yang terbuang keluar akibat dari tidak dapat terkondensasi dengan baik oleh kondensor. Sebaliknya dengan suhu destilasi yang tinggi dan laju penguapan (produksi uap) juga tinggi maka akan semakin banyak uap asap cair yang tidak dapat terkondensasi menjadi cairan akibat terbuang keluar pipa kondensor sehingga efisiensinya juga kecil. 


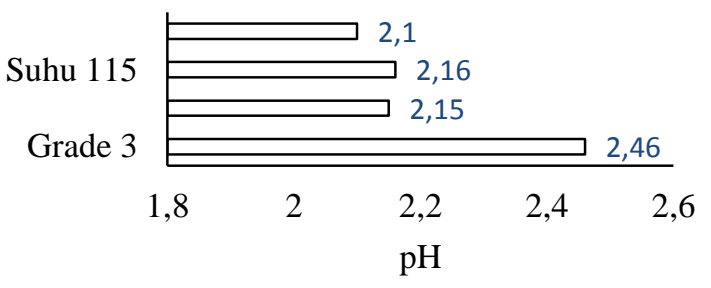

Gambar 6. Grafik perbandingan $\mathrm{pH}$

Pada penelitian ini diketahui bahwa semakin besar suhu yang digunakan akan menghasilkan kualitas asap cair yang lebih baik namun berbanding terbalik dengan banyaknya asap cair yang dihasilkan semakin besar suhu maka asap cair yang dihasilkan semakin sedikit. Pada proses destilasi senyawa yang memiliki titik didih yang lebih tinggi, namun lebih larut dalam air akan menguap terlebih dahulu bila dibandingkan dengan senyawa yang titik didihnya rendah tetapi kelarutanya dalam air rendah [7-20].

Kandungan $\mathrm{pH}$ asap cair hasil destilasi pada variasi waktu juga meningkat dengan bertambahnya waktu destilasi. Artinya kadar asam yang terdapat pada asap cair hasil destilasi menurun dengan meningkatnya waktu destilasi. Hal tersebut dimungkinkan masih adanya air yang terikut pada pemisahan asam asetat dengan destilasi tersebut, sehingga menyebabkan nilai derajat keasaman juga meningkat. Dibandingkan dengan nilai $\mathrm{pH}$ dari asap cair sebelum didestilasi, $\mathrm{pH}$ asap cair hasil destilasi lebih kecil dari yang sebelum didestilasi.

\section{Kesimpulan}

Dari penelitian yang telah dilakukan dari pengujian, pengambilan data dan analisa data dapat disimpulkan bahwa suhu destilasi berpengaruh terhadap laju pemanasan yang terjadi yaitu suhu destilasi $110^{\circ} \mathrm{C}$ laju pemanasan $707,42 \mathrm{~J} /$ detik, pemakaian listrik $4,48 \mathrm{kWh}$, waktu 45 menit, dan untuk suhu $120{ }^{\circ} \mathrm{C}$ laju pemanasan 754,60 J/detik, pemakaian listrik 4,467 kWh waktu 65 menit. Hasil asap cair terbanyak yaitu pada suhu $110^{\circ} \mathrm{C}$ yaitu $2840 \mathrm{ml}$ dengan debit aliran 8,35 $\mathrm{ml} / \mathrm{menit}$ dan efisiensi 94,6\%, kadar $\mathrm{pH}$ 2,15. Dan untuk suhu $120{ }^{\circ} \mathrm{C}$ menghasilkan asap cair $2560 \mathrm{ml}$, dengan debit aliran 8,67 $\mathrm{ml} /$ menit dan efisiensi $85,3 \%$, kadar $\mathrm{pH}$ 2,10 .

\section{Ucapan terima kasih}

Penulis mengucapkan banyak
terima kasih kepada kepada Rektor
Universitas Muhammadiyah Metro yang
telah memberikan bantuan dana penelitian
ini, dan Ketua Lembaga Penelitian dan
Pengabdian kepada Masyarakat Universitas
Muhammadiyah Metro, serta rekan-rekan
dijajaran Program studi Teknik Mesin UM
Metro yang telah mambantu, dan tidak lupa
Mahasiswa Teknik Mesin yang terlibat
dalam penelitian ini. Terima kasih
semuanya.

\section{Referensi}

[1] Harinen, S. , 2004, Analysis of The Top Phase Fraction of Wood Pyrolysis Liquids, Master Thesis, Laboratory of Applied Chemistry, Department of Chemistri, University of Jyvaskyla.

[2] Hambali E., Mujdalifah S., Tambunan AH, Pattiwiri AW, Hendroko R., (2007), Teknologi Bioenergi", Agro Media Pustaka, Jakarta.

[3] Fachraniah, Fona, Z., dan Rahmi, Z., (2009), "Peningkatan Kualitas Asap Cair dengan Destilasi”, Jurnal Reaksi, Vol. 7(14), pp. 1-11.

[4] Yaman, S., 2004, "Pyrolysis of biomass to produce fuels and chemical Feedstocks", Energy Conversion and Management, 45, 651-671.

[5] Darmadji P., (2002), "Optimasi Pemurnian Asap Cair dengan Metode Redestilasi”, Jurnal Teknologi dan Industri Pangan, Vol. XIII (3), hal 267-271 
[6] Ridhuan, Kemas,. Mafrudin, Alrasyd, Alfi,. 2020, Optimasi Pembakaran Menyeluruh Pada Reaktor Pirolisis Dalam Menghasilkan Bioarang Dan Asap Cair, Jurnal Teknik Mesin Turbo, Vol 9, No 1 Juni 2020, Halaman 69 - 78, ISSN 2301-6663, ISSNe : 2477-259X

[7] Yulistiani, R., (2008), Monograf Asap Cair Sebagai Bahan Pengawet Alami Pada Produk Daging dan Ikan, UPN Veteran, Jawa Timur, Surabaya, hal 50-53.

[8] Ridhuan, Kemas. Arya, Sepit. 2015. Karaktristik Pembakaran berbagai Jenis Bahan Limbah Biomassa dengan Menggunakan Proses Nonkarbonisasi. Jurnal Teknik Mesin "Turbo". Volume 4 Nomor 1. ISSN: 23016663

[9] Anonim. 2010. Asap cair. https://id.wikipedia.org/wiki/Asap_ cair (4 Juli 2011).

[10] Demirbas, A., 2005., Pyrolysis Of Ground Beech Wood In Irregular Heating Rate Conditions. Journal Of Analytical Applied And Pyrolysis 73:39-43.

[11] Devison. (2015). Rekayasa Pirolisator Berkinerja Tinggi Untuk Peningkatan Rendemen Asap Cair. Thesis Program Studi Teknologi Pertanian Universitas Andalas, Padang.

[12] Fatimah, Is. 2004, Pengaruh Laju Pemanasan Terhadap Komposisi Biofeul Hasil Pirolisis Serbuk Kayu, Jurnal Logika, Vol.1 No.1 Issn:1410-2315 - Hlm.46-50.

[13] Jamilatun, Siti. Maryudi. Setyawan, Martomo, 2013, Kinerja Kombinasi Dari Alat Pirolisis Dengan Destilasi Secara Sinambung Dalam Memproduksi Asap Cair Tempurung Kelapa, Prosiding Seminar Nasional Teknoin, Vol.3, Isbn 978-602-14272-0-0. Hlm. 4046.
[14] Mappiratu, 2009, Kajian Teknologi Produksi Asap Cair Dari Sabut Kelapa, Media Litbang Sulteng 2 (2), Issn.1979-5971. Hlm. 104-109

[15] Mulyadi, Edi, 2010, Kinetika Reaksi Pembentukan Bio-Oil Pada Dekomposisi Gambut Dalam Reaktor Batan, Prosiding Seminar Nasional Pengembangan Energi Nuklir III, Pusat Pengembangan Energi Nuklir Badan Tenaga Nuklir Nasional, 407 Issn 1979-1208. Hlm. 407-412.

[16] Pszcola DE. 1995. Tour Highlights Production and Uses of Smoke House Base Flavors. J Food Tech 49: 70-74.

[17] Soldera S, Sebastianutto N, Bortolomeazzi R. 2008. Composition of Phenolic Compounds And Antioxidant Activity Of Commercial Aqueous Smoke Flavorings. J Agric Food Chem 56: 2727-2734

[18] Wibowo, Santiyo. 2013, Karakteristik Bio-Oil Serbuk Gergaji Sengon Menggunakan Proses Pirolisis Lambat Paraserianthes Falcatari,Jurnal Penelitian Hasil Hutan Vol. 31 No. 4, Issn: 0216-4329 - Hlm.258-270.

[19] Wijayanti, Widya. Nur, Mega Sasongko. Dkk., 2013, Metode Pirolisis Untuk Penanganan Sampah Perkotaan Sebagai Penghasil Bahan Bakar Alternatif, Jurnal Rekayasa Mesin, Vol.4, No.2, ISSN 0216468X, Hlm. 85-92

[20] Wulandari, Puri Rahayu, 2012, Produksi Minyak Bio Pirolitik Dari Reaksi Fast Pyrolysis Biomassa Sekam Padi (Oryza Sativa L.) Menggunakan Reaktor Bubbling Fluidized Bed Sebagai Bahan Bakar Alternatif Green Diesel), Skripsi tidak dipublikasikan, Jakarta, Prodi Kimia Fakultas Matematika Dan Ilmu Pengetahuan Alam Universitas Indonesia. 